\title{
INDEX TO Volume 25 (2007)
}

\section{ArTiCles}

BAUBÉROT, Jean. Existe-t-il une religion civile républicaine? (Vol. 25, No. 2, 3)

BAUDOUIN, Thierry and COLLIN, Michèle. L'enjeu métropolitain des Halles (Vol. 25, No. 2, 94)

BRACHER, Nathan. Soixante ans après: pour un état des lieux de mémoire (Vol. 25, No. 1, 49)

BROWN, Laurence. "Pour Aider Nos Frères d'Espagne": Humanitarian Aid, French Women, and Popular Mobilization during the Front Populaire (Vol. 25, No. 1, 30)

CESARI, Jocelyne. The Muslim Presence in France and the United States: Its Consequences for Secularism (Vol. 25, No. 2, 34)

CHAPMAN, Herrick. Introduction (Vol. 25, No. 2, 1)

DIMÉGLIO, Pierre and ZETLAOUI-LÉGER, Jodelle. Les rapports ambigus entre politiques et citoyens: le cas du réaménagement du quartier des Halles à Paris (Vol. 25, No. 2, 116)

GRUNBERG, Gérard. Les élections françaises de 2007 (Vol. 25, No. 3, 62)

LÉVY, Jacques. France, une géographie à inventer (Vol. 25, No. 1, 70)

MATONTI, Frédérique. La singularité française: la campagne présidentielle de Ségolène Royal (Vol. 25, No. 3, 86)

MILES, William. Once Again, From a Distance: Martinique and the French Presidential Election of 2007 (Vol. 25, No. 3, 102)

PERRINEAU, Pascal. Analyse de l'élection présidentielle des 22 avril et 6 mai et des élections législatives des 10 et 17 juin 2007: une rupture politique? (Vol. 25, No. 3, 74)

RANDAXHE, Fabienne. Religion, politique et régulation juridique aux ÉtatsUnis (Vol. 25, No. 3, 19)

ROCHEFORT, Florence. Religions, genre, et politiques laïques en France, XIX ${ }^{\mathrm{e}}$-XX ${ }^{\mathrm{e}}$ siècles (Vol. 25, No. 2, 19)

ROSENBLATT, Helena. On the Intellectual Sources of Laïcité: Rousseau, Constant, and the Debates about a National Religion (Vol. 25, No. 3, 1) 
SAPIRO, Gisèle. The Writer's Responsibility in France: From Flaubert to Sartre (Vol. 25, No. 1, 1)

TENHOOR, Meredith. Architecture and Biopolitics at Les Halles (Vol. 25, No. 2, 73)

WAKEMAN, Rosemary. Fascinating Les Halles (Vol. 25, No. 2, 46)

WILLAIME, Jean-Paul. Religion et politique en France dans le contexte de la construction européenne (Vol. 25, No. 3, 37)

ReVIEW Essays

COFFIN, Judith. Historicizing The Second Sex (Vol. 25, No. 3, 123)

MOURÉ, Kenneth. Economic Choice in Dark Times: The Vichy Economy (Vol. 25, No. 1, 108)

POPKIN, Jeremy D. Revolution in the Colonies and the French Republican Tradition (Vol. 25, No. 1, 95)

REID, Donald. Available in Hell: Germaine Tillion's Operetta of Resistance at Ravensbrück (Vol. 25, No. 2, 141)

Book Reviews

BENOÎT, Catherine. Essais de poétique des jardins by Michel Conan (Vol. 25, No. 1, 131)

BLEICH, Erik. Getting into Local Power: The Politics of Ethnic Minorities in British and French Cities by Romain Garbaye (Vol. 25, No. 2, 153)

BOURG, Julien. French Intellectuals Against the Left: The Anti-Totalitarian Moment of the 1970s in French Intellectual Politics by Michael Scott Christofferson (Vol. 25, No. 1, 140)

INGRAM, Mark. Renouveau et décentralisation du théâtre 1945-1981 by Pascale Goetschel (Vol. 25, No. 2, 151)

KIESLING, Eugenia. The Tour de France by Christopher Thompson (Vol. 25, No. 3, 151)

LÉPINARD, Éléonore. Gender Quotas, Parity Reform, and Political Parties in France by Katherine A. R. Opello (Vol. 25, No. 3, 153)

LEWIS-BECK, Michael S. Le Nouveau Désordre électoral: Les Leçons du 21 avril 2002 by Bruno Cautrès and Nonna Mayer (Vol. 25, No. 1, 143)

QUINLAN, Sean M. Patriotic Taste: Collecting Modern Art in Pre-Revolutionary Paris by Colin B Bailey (Vol. 25, No. 3, 149)

SCHOOLCRAFT III, Ralph. Harnessing the Holocaust: The Politics of Memory in France by Joan B. Wolf (Vol. 25, No. 1, 135)

INDEX OF BoOKs Reviewed

BAILEY, Colin B. Patriotic Taste: Collecting Modern Art in Pre-Revolutionary Paris reviewed by Sean M. Quinlan (Vol. 25, No. 3, 149) 
CAUTRÈS, Bruno and MAYER, Nonna. Le Nouveau Désordre électoral: Les Leçons du 21 avril 2002 reviewed by Michael S. Lewis-Beck (Vol. 25, No. 1, 143)

CHRISTOFFERSON, Michael Scott. French Intellectuals Against the Left: The Anti-Totalitarian Moment of the 1970s in French Intellectual Politics reviewed by Julien Bourg (Vol. 25, No. 1, 140)

CONAN, Michel. Essais de poétique des jardins reviewed by Catherine Benoît (Vol. 25, No. 1, 131)

GARBAYE, Romain. Getting into Local Power: The Politics of Ethnic Minorities in British and French Cities reviewed by Erik Bleich (Vol. 25, No. 2, 153)

GOETSCHEL, Pascale. Renouveau et décentralisation du théâtre 1945-1981 reviewed by Mark Ingram (Vol. 25, No. 2, 151)

OPELLO, Katherine A. R. Gender Quotas, Parity Reform, and Political Parties in France reviewed by Éléonore Lépinard (Vol. 25, No. 3, 153)

THOMPSON, Christopher. The Tour de France reviewed by Eugenia Kiesling (Vol. 25, No. 3, 151)

WOLF, Joan B. Harnessing the Holocaust: The Politics of Memory in France reviewed by Ralph Schoolcraft III (Vol. 25, No. 1, 135) 